\title{
Prolactin-Stat5 signaling in breast cancer is potently disrupted by acidosis within the tumor microenvironment
}

Ning Yang ${ }^{1}$, Chengbao Liu' ${ }^{1}$, Amy R Peck ${ }^{1}$, Melanie A Girondo ${ }^{1}$, Alicia F Yanac ${ }^{1}$, Thai H Tran ${ }^{1}$, Fransiscus E Utama ${ }^{1}$, Takemi Tanaka ${ }^{4}$, Boris Freydin ${ }^{5}$, Inna Chervoneva ${ }^{5}$, Terry Hyslop ${ }^{5}$, Albert J Kovatich ${ }^{6}$, Jeffrey A Hooke?, Craig D Shriver ${ }^{7}$ and Hallgeir Rui ${ }^{1,2,3,8^{*}}$

\begin{abstract}
Introduction: Emerging evidence in estrogen receptor-positive breast cancer supports the notion that prolactinStat5 signaling promotes survival and maintenance of differentiated luminal cells, and loss of nuclear tyrosine phosphorylated Stat5 (Nuc-pYStat5) in clinical breast cancer is associated with increased risk of antiestrogen therapy failure. However, the molecular mechanisms underlying loss of Nuc-pYStat5 in breast cancer remain poorly defined.

Methods: We investigated whether moderate extracellular acidosis of pH 6.5 to 6.9 frequently observed in breast cancer inhibits prolactin-Stat5 signaling, using in vitro and in vivo experimental approaches combined with quantitative immunofluorescence protein analyses to interrogate archival breast cancer specimens.

Results: Moderate acidosis at pH 6.8 potently disrupted signaling by receptors for prolactin but not epidermal growth factor, oncostatin M, IGF1, FGF or growth hormone. In breast cancer specimens there was mutually exclusive expression of Nuc-pYStat5 and GLUT1, a glucose transporter upregulated in glycolysis-dependent carcinoma cells and an indirect marker of lactacidosis. Mutually exclusive expression of GLUT1 and Nuc-pYStat5 occurred globally or regionally within tumors, consistent with global or regional acidosis. All prolactin-induced signals and transcripts were suppressed by acidosis, and the acidosis effect was rapid and immediately reversible, supporting a mechanism of acidosis disruption of prolactin binding to receptor. T47D breast cancer xenotransplants in mice displayed variable acidosis ( $\mathrm{pH} 6.5$ to 6.9) and tumor regions with elevated GLUT1 displayed resistance to exogenous prolactin despite unaltered levels of prolactin receptors and Stat5.
\end{abstract}

Conclusions: Moderate extracellular acidosis effectively blocks prolactin signaling in breast cancer. We propose that acidosis-induced prolactin resistance represents a previously unrecognized mechanism by which breast cancer cells may escape homeostatic control.

Keywords: Breast cancer, Extracellular acidosis, Tumor microenvironment, Prolactin, Prolactin receptor, Stat5

\section{Introduction}

Extracellular acidosis is a frequent feature of the microenvironment in solid tumors, and acidosis is considered one of the major selective forces that promote evolution of aggressive and drug-resistant tumor clones [1]. Enhanced glycolysis with lactacidosis is a key contributor

\footnotetext{
* Correspondence: hallgeir.rui@jefferson.edu

'Department of Cancer Biology, Kimmel Cancer Center, Thomas Jefferson

University, 233 South 10th Street, Philadelphia, PA 19107, USA

${ }^{2}$ Department of Pathology, Kimmel Cancer Center, Thomas Jefferson

University, 233 South 10th Street, Philadelphia, PA 19107, USA

Full list of author information is available at the end of the article
}

to reduced extracellular $\mathrm{pH}\left(\mathrm{pH}_{\mathrm{e}}\right)$ in tumors [2]. In vivo measurements have revealed $\mathrm{pH}_{\mathrm{e}}$ values of 6.5 to 6.9 in human breast cancer and other malignant tumors compared to normal tissue $\mathrm{pH}_{\mathrm{e}}$ values of 7.2 to $7.4[3,4]$. Cancer cell glycolysis may be anaerobic as a consequence of hypoxia (the Pasteur effect) or aerobic due to metabolic reprogramming even under normoxic conditions (the Warburg effect) [5]. In addition, glycolysis in cancer-associated fibroblasts may contribute to extracellular acidosis in the tumor microenvironment [6]. Importantly, extracellular acidosis of malignant tumors

\section{Biomed Central}


potentiates cancer progression by facilitating tumor invasion $[7,8]$, suppressing immune responses [9] and promoting metastasis in mouse models [10,11]. Elevated lactic acid secretion and acidosis were also associated with higher incidence of metastases in various human cancers [12,13]. However, the molecular mechanisms underlying selection for more aggressive cancer clones during acidosis remain incompletely understood and may vary between cancer types.

In breast cancer, prolactin has been implicated as a tumor promoter based on experimental studies in rodents $[14,15]$ and the association between elevated circulating prolactin levels and increased risk of developing breast cancer [16]. Prolactin sustains nuclear tyrosine phosphorylated Stat5 (Nuc-pYStat5) and supports survival and expansion of differentiated luminal breast epithelial cells $[17,18]$ and maintains their sensitivity to cell death [19]. In breast cancer cell lines, experimental activation of Stat5 promotes differentiation, inhibits invasive characteristics [20-22], and blocks progesterone-induced emergence of a drug-resistant CK5-positive cell population [23] with tumor-initiating characteristics [24-26]. In clinical breast cancer specimens, loss of Nuc-pYStat5 is associated with poor prognosis and increased risk of tamoxifen resistance [27-30]. Thus, a dual role of prolactin-Stat 5 signaling in breast cancer has been proposed, wherein initial pathway activation promotes cell survival and tumor formation, whereas differentiationpromoting effects of prolactin-Stat 5 signaling may support homotypic adhesion and suppress subsequent invasive behavior and progression [31]. However, little is known about the molecular causes for frequent loss of Stat 5 tyrosine phosphorylation in human breast cancer.

Intriguingly, surface plasmon resonance studies have shown that prolactin interaction with its receptor is disrupted at $\mathrm{pH}$ of 6.0 or lower [32]. Such low $\mathrm{pH}$ occurs in early endosomes and in prolactin secretory vesicles of pituitary lactotrophs and may facilitate recycling of prolactin receptors and reversible prolactin aggregation, respectively [32]. Although $\mathrm{pH}_{\mathrm{e}}$ lower than 6.5 rarely occurs in extracellular space of solid tumors, it has remained unclear, based on limited in vitro experiments [32-34], whether such moderate extracellular acidosis of the microenvironment of breast cancer affects prolactin signaling. Based on in vitro and in vivo experimental approaches and extensive quantitative in situ analyses of human breast cancer specimens, we now demonstrate that prolactin activation of prolactin receptors is selectively disrupted even at mildly acidic $\mathrm{pH}_{\mathrm{e}}$ of 6.8. The new observations identify acidosis as a significant contributor to loss of Nuc-pYStat5 in clinical breast cancer specimens, and implicate acidosis-induced prolactin resistance as a previously unrecognized mechanism by which breast cancer cells may evade homeostatic control.

\section{Methods}

\section{Cell culture, reagents and antibodies}

T47D, SKBR3, MDA-MB-468, MCF-7 and BT474 cells (ATCC, Manassas, VA, USA) were cultured as previously described [35]. Mouse promyeloid 32D cells stably transfected with human prolactin receptors (32D-hPrlR cells) or human growth hormone $(\mathrm{GH})$ receptors (32DhGHR cells), were cultured as previously described [36]. Recombinant human prolactin and human $\mathrm{GH}$ were purchased from Dr. A. F. Parlow under the sponsorship of the National Hormone and Pituitary Program. Epidermal growth factor (EGF) was from Peprotech (Rocky Hill, NJ, USA). Monoclonal anti-pY-Stat5 (AX1) and rabbit antisera to Jak1 and Stat3, Stat5a and Stat5b were provided by Advantex BioReagents (Houston, TX, USA). Monoclonal Stat5, Jak1 and Erk antibodies were from BD Transduction Laboratories (Lexington, KY, USA). Monoclonal Jak2 antibody was from Biosource (Camarillo, CA, USA). Mouse monoclonal antibodies to phosphothreonine/ tyrosine-ERK1/2 and phosphotyrosine-Stat3 were from Cell Signaling Technology (Beverly, MA, USA). Polyclonal antibody anti-Stat5 was from Santa Cruz Biotechnology (Santa Cruz, CA, USA). Rabbit anti-JAK2 antibody and mouse anti-phosphotyrosine antibody (4G10) were from Millipore (Billerica, MA, USA). Monoclonal antibodies used for immunohistochemistry include anti-pancytokeratin, anti-estrogen receptor (ER) (1D5), anti-progesterone receptor (PR) (PgR636) and antiKi67 (MIB-1) from Dako (Carpinteria, CA, USA), pY-Stat5 antibody (Epitomics, Burlingame, CA, USA), anti-glucose transporter 1 (GLUT1) from Thermo Fisher Scientific (Fremont, CA, USA), antiPrlR (ECD) (1A2B1; Invitrogen, Carlsbad, CA, USA) and anti-lactate dehydrogenase-5 (LDH5) (Abcam, Cambridge, CA, USA).

\section{Three-dimensional cell culture}

To generate three-dimensional spheroids of T47D cells, one million cells were loaded into a rotating bioreactor (Rotary Cell Culture System; Synthecon, Houston, TX, USA) and cultured at 7 to $8 \mathrm{rpm}$ in buffered RPMI supplemented with $10 \%$ fetal calf serum (FCS) at $37^{\circ} \mathrm{C}$ for $36 \mathrm{~h}$ in a CO2 incubator. Spheroids (1 to $2 \mathrm{~mm}$ in diameter) were collected and transferred to serum-free medium with or without prolactin at $\mathrm{pH} 6.8$ or 7.4 as indicated. Spheroids were then immediately formalin-fixed and paraffin-embedded.

\section{Cell stimulation, protein extraction, immunoprecipitation, and immunoblotting}

For breast cancer cell lines, confluent cells were serumstarved overnight in culture medium, then incubated in fresh buffered RPMI (supplemented with 25 mM HEPES and $35 \mathrm{mM}$ MOPS, adjusted to desired $\mathrm{pH}$ ) for $15 \mathrm{~min}$ at $37^{\circ} \mathrm{C}$ before stimulation. Hormone or growth factor 
treatments were carried out at $37^{\circ} \mathrm{C}$ for $15 \mathrm{~min}$, unless otherwise specified. 32D-hPrlR and 32D-hGHR cells were serum-starved for $5 \mathrm{~h}$ before stimulation. Cell stimulation, protein extraction, immunoprecipitation and immunoblotting were performed as described [35]. Briefly, for detection of pYStat5, pYJak1 or pYJak2, cell lysates were first immuoprecipitated with anti-Stat5, anti-Jak1 or anti-Jak2 antibodies and proteins were separated by SDS-PAGE. Immunoblotting with anti-pYStat 5 for detecting pY-Stat5 or anti-phosphotysine (4G10) for detecting pYJak1 and pYJak2 was then conducted. For detection of other proteins whole cell lysates were used in western blotting.

\section{Quantitative RT-PCR}

qRT-PCR assays were performed with RNA isolated from SKBR3 cells using RNeasy kit (Qiagen, Venlo, Netherlands). cDNA was generated using Iscript (BioRad, Hercules, CA, USA) and subjected to quantitative PCR using forward/reverse primers CISH-f/r(CTGC TGTGCATAGCCAAGAC/GTGCCTTCTGGCATCTT CTG) and c-JUN-f/r(CACGTTAACAGTGGGTGCCA/ CCCCGACGGTCTCTCTTCA).

\section{T47D xenograft tumors, prolactin treatment and tumor $\mathrm{pH}_{\mathrm{e}}$ measurement in vivo}

T47D xenotransplants were grown as previously described [36]. Animal studies reported here adhered to international guidelines of ethical conduct and were approved by Thomas Jefferson University Institutional Animal Care and Use Committee under protocol 789D to HR. Briefly, 5 - to 7 -week-old female nude mice implanted with $17 \beta$ estradiol pellets $(0.72 \mathrm{mg}$; Innovative Research of America, Sarasota, FL, USA) were injected subcutaneously with $5 \times$ $10^{6}$ T47D cells into two flank sites. For in vivo prolactin treatment, tumor-bearing mice were injected intraperitoneally with either vehicle control $(n=3)$ or $1 \mu \mathrm{g} / \mathrm{g}$ body mass of human prolactin $(n=3)$. One $\mathrm{h}$ after injection, mice were euthanized and tumors collected. The in vivo prolactin treatment experiment was independently repeated a second time. In vivo tumor $\mathrm{pH}$ measurements were performed individually on a total of nine anesthetized T47D tumor-bearing mice by inserting a miniature pH electrode (IC 501; Samuel Agulian, Hamden, CT, USA) 2 to $4 \mathrm{~mm}$ into the tumor through a small skin incision. In vivo intraperitoneal $\mathrm{pH}$ measurement was carried out in parallel in three of the same anesthetized T47D tumor-bearing mice by inserting the micro $\mathrm{pH}$ electrode into the peritoneal cavity through a skin incision. The mice were euthanized after the procedures.

\section{Breast tumor specimens}

Two cohorts of archival and de-identified formalin-fixed, paraffin-embedded breast cancer specimens were analyzed under Thomas Jefferson University Institutional Review Board approved protocol 09G.355. Cohort I was from Walter Reed National Military Medical Center (Bethesda, MD, USA) and represented whole tissue sections from patients with invasive carcinomas. Histology, ER/PR, Ki67 and PrlR were evaluated by a pathologist. Cohort II was a breast cancer progression array of specimens from Thomas Jefferson University (Philadelphia, PA, USA) constructed by cutting edge matrix assembly [37], comprising 40 healthy breast tissues and 140 breast carcinoma specimens, including ductal carcinoma in situ, primary invasive ductal carcinomas (grades 1 to 3 ), and lymph node metastases [38].

\section{Immunohistochemistry (IHC) and quantification}

IHC and automated quantitative analysis (AQUA) were performed as described previously [38]. Briefly, fluorescent images of stained slides were captured in three channels (FITC/Alexa-488, Cy5, or DAPI). AQUA scores for pYStat 5 and GLUT1 represent average signal intensity within the epithelial cell population as defined by cytokeratin positivity. Cell-based quantitative analysis was performed using Tissue Studio (Definiens, Parsippany, NJ, USA).

\section{Densitometric and statistical analysis}

Immunoblots were scanned and densitometric quantification of images exposed in the linear range was performed using Image J (NIH, Bethesda, MD, USA). Data from at least three experiments are presented as mean \pm standard error (SE). Statistical significance of differences was estimated by $t$ test or analysis of variance (ANOVA). Association between Nuc-pYStat5 and GLUT1 was evaluated in Cohort I and II of patientderived specimens. For AQUA, quantification of NucpYStat 5 and cytoplasmic GLUT1 were obtained at whole tissue, regional, and cellular levels of Cohort I. Based on discrete distribution of the AQUA score, Nuc-pYStat5 scores above $65^{\text {th }}$ percentile of whole tissue level were defined as high and GLUT1 scores above $83^{\text {rd }}$ percentile of whole tissue level were defined as positive. At the whole tissue level, Fisher's exact test was used to analyze association between Nuc-pYStat5 levels (high vs. low) and other tumor variables. Because multiple spots from each tumor section were used to obtain regional information, analyses at the regional level employed the generalized linear mixed-effects model to model levels of Nuc-pYStat 5 with the random effect of slide and fixed effect of GLUT1. For Tissue Studio analyses, quantification of Nuc-pYStat5 and GLUT1 levels at the cellular level, corresponding percentile cut points were used to partition the staining levels into high and low. Cellular Nuc-pYStat5 levels were analyzed in logistic regression model with GLUT1 levels as predictor. Data were 
analyzed in R 2.14 (R Foundation for Statistical Computing, [39]) and SAS 9.3 (SAS Institute Inc., Cary, NC, USA).

\section{Results \\ Prolactin activation of Stat5 in human breast cancer cell lines is disrupted by moderate extracellular acidosis}

Prolactin responsiveness of five human breast cancer cell lines, including ER-positive T47D, MCF7 and BT474 and ER-negative SKBR3 and MDA-MB-468, was analyzed at $\mathrm{pH}_{\mathrm{e}}$ of 6.8 and at normal tissue $\mathrm{pH}_{\mathrm{e}}$ of 7.4. Each of the five cell lines responded to prolactin by inducible tyrosine phosphorylation of Stat 5 at normal tissue $\mathrm{pH}_{\mathrm{e}}$ of 7.4, whereas prolactin-induced Stat5 phosphorylation was abolished or nearly abolished at $\mathrm{pH}_{\mathrm{e}} 6.8$ (Figure 1A). We conclude that prolactin-induced Stat 5 activation in human breast cancer cell lines is highly sensitive to moderate $\mathrm{pH}$ reduction.

\section{Mutually exclusive expression of nuclear localized, tyrosine phosphorylated Stat5 and GLUT1 in clinical human breast cancer specimens}

To establish initial clinical relevance for the in vitro observations, we tested the hypothesis that levels of nuclear localized and tyrosine phosphorylated Stat5 (Nuc-pYStat5) would be low in human breast cancer specimens expressing elevated levels of GLUT1, a glucose transporter. GLUT1 is upregulated in breast carcinoma cells with elevated glycolytic metabolism and lactic acid production [40]. Whole tumor tissue sections from a cohort of 52 invasive breast cancer specimens were analyzed using the multiplexed and immunofluorescencebased AQUA platform [29,38]. Indeed, Nuc-pYStat5 status was negatively associated with GLUT1 status (Fisher's exact test, $p=0.009$ ), but not with levels of PrlR, ER/PR expression, histological classification (ductal vs. lobular), or proliferation index Ki67 (Table 1). While ER/PR-negative tumors were associated with positive GLUT1 expression $(p<0.01)$, Nuc-pYStat5 status was not significantly associated with ER/PR status.

When levels of GLUT1 expression within each cancer specimen were plotted against levels of Nuc-pYStat5, all tumors with elevated GLUT1 levels displayed low levels of Nuc-pYStat5, whereas all cases with high levels of Nuc-pYStat5 expressed low levels of GLUT1 (Figure 1B). This is consistent with mutually exclusive patterns of positive staining for GLUT1 and Nuc-pYStat5 at the global tumor level. However, since some Nuc-pYStat5-positive breast cancer cases display heterogeneous staining patterns with regional intratumoral loss of Nuc-pYStat5 (for example Figure 1C), we determined at a more refined scale whether mutually exclusive expression of GLUT1 and Nuc-pYStat5 also existed at the regional level within tumors. We co-stained and re-quantified levels of GLUT1 and Nuc-pYStat 5 in the same 52 breast cancer specimens based on sampling of a total of 2,244 nonoverlapping $0.6 \mathrm{~mm}^{2}$ tumor regions. Also at this local scale, regions with high GLUT1 levels consistently displayed low Nuc-pYStat5 levels (Figure 1D, panel 1), whereas regions with high Nuc-pYStat5 intensities were associated with low GLUT1 levels (Figure 1D, panel 3). Partitioning of the sampled regions into either high or low GLUT1 or Nuc-pYStat5 levels revealed that areas with high GLUT1 levels had 1.72-fold elevated odds of displaying low Nuc-pYStat5 levels (odds ratio $=1.72$, 95\%CI: 1.12 to $2.66 ; p=0.013)$.

Intriguingly, even among the sampled 2,244 tumor regions of $0.6 \mathrm{~mm}^{2}$ many still displayed heterogeneous positivity for either marker, but rarely did cells appear doubly positive for both markers (see representative image in Figure 1D, panel 2). We therefore further examined the relationship between GLUT1 and NucpYStat5 levels within a subset of tumors exhibiting staining heterogeneity, and resolved marker expression at the single cell level using cell segmentation software. In total, images of six tumors co-stained for GLUT1 and Nuc-pYStat5 were analyzed to generate 8,804 cellular data points (Figure 1E, upper panels). A scatter plot of histocytometric GLUT1 and Nuc-pYStat5 values revealed continued mutually exclusive staining pattern between the two markers also at this scale (Figure 1E, lower panel). The odds of cells expressing low levels of Nuc-pYStat5 were 1.9-fold higher when the cells expressed high levels of GLUT1 (odds ratio $=1.9$, 95\% confidence interval $(\mathrm{CI}): 1.62$ to $2.25 ; p<0.0001)$. Collectively, the quantitative analyses of clinical breast cancer specimens revealed a robust mutually exclusive pattern of expression between high GLUT1 and NucpYStat5 levels, a relationship that persisted across all levels examined including at the global tumor tissue, locoregional, and cellular levels.

\section{Acidosis-induced disruption of all signals downstream of prolactin receptors}

Acidosis might affect prolactin-Stat 5 signaling in breast cancer cells by mechanisms beyond disrupting prolactin receptor-ligand binding. However, if the principal mechanism involved is $\mathrm{pH}_{\mathrm{e}}$-dependent disruption of receptorligand binding, then the effect on prolactin signaling would not be limited to Stat 5 but include disruption of all signals downstream of the prolactin receptor. Indeed, in both T47D and SKBR3 cells all major prolactinactivated signaling pathways were inhibited at $\mathrm{pH}_{\mathrm{e}}$ of 6.8, including inducible phosphorylation of Jak2, Jak1, signal transducer and activator of transcription-5a (Stat5a), signal transducer and activator of transcription-5b (Stat5b), Stat3 and Erk (Figure 2A). We next characterized the proton concentration-dependence of prolactin-responsiveness 


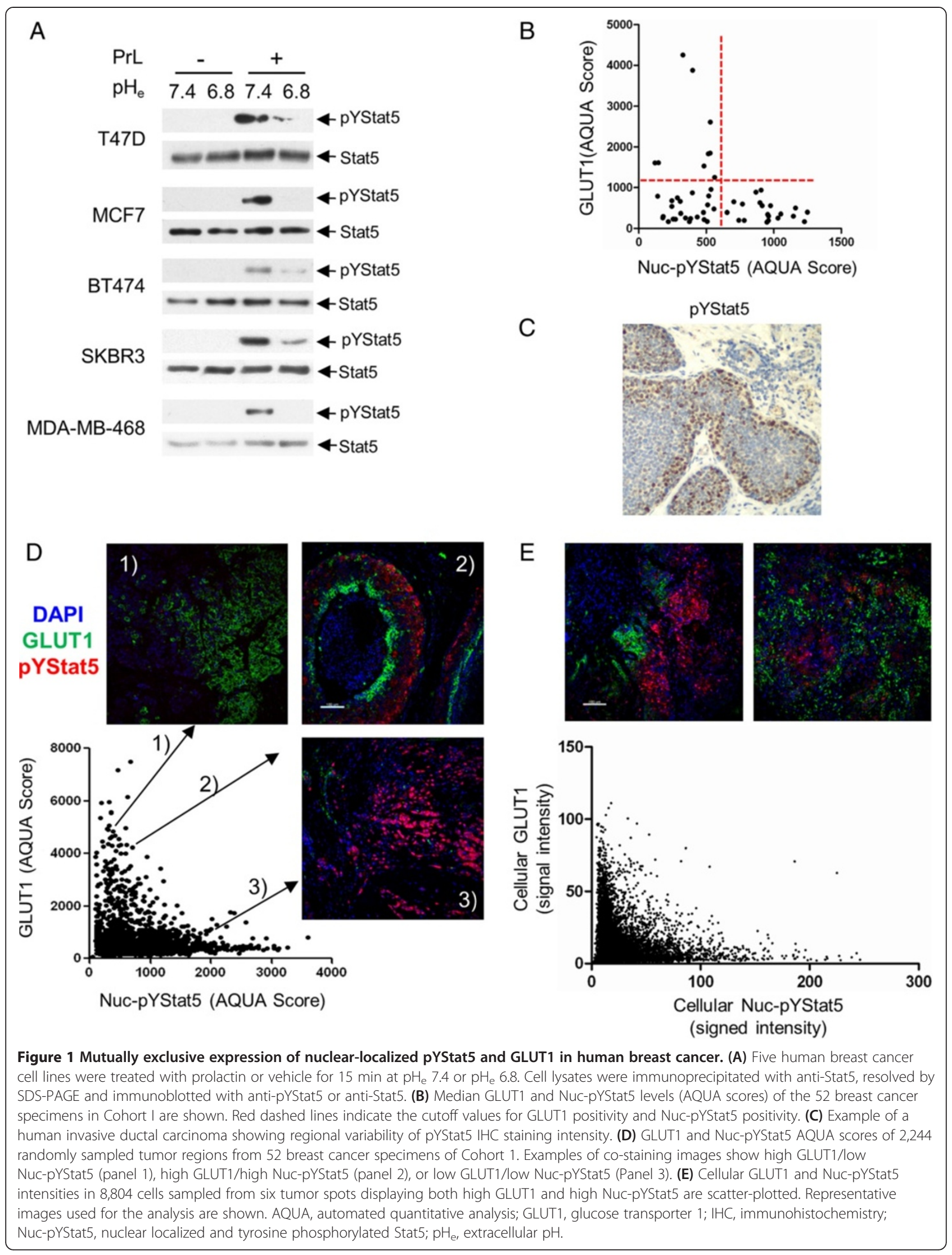


Table 1 Relationship between levels of Nuc-pYStat5 and other tumor variables in Cohort I

\begin{tabular}{lcccc}
\hline & & \multicolumn{2}{c}{ Nuc-pYStat5 $\boldsymbol{n}(\%)$} & $\begin{array}{c}\text { Fisher's } \\
\text { exact test, } \boldsymbol{P}\end{array}$ \\
\cline { 3 - 4 } & High & Low & 0.009 \\
\hline GLUT1 & High & $0(0)$ & $9(100)$ & \\
\multirow{2}{*}{ PrIR } & Low & $20(46.5)$ & $23(53.5)$ & \\
& High & $9(45)$ & $11(55)$ & 0.561 \\
Ki67 & Low & $11(34.4)$ & $21(65.6)$ & \\
& $>=15 \%$ & $11(35.5)$ & $20(64.5)$ & 0.770 \\
Histology & IDC & $18(39.1)$ & $28(60.9)$ & 0.784 \\
& ILC & $2(50)$ & $4(50)$ & \\
ER/PR & Positive & $18(45.0)$ & $22(55.0)$ & 0.100 \\
& Negative & $2(16.7)$ & $10(83.3)$ & \\
Total & & $\mathbf{2 0 ( 3 8 . 5 )}$ & $\mathbf{3 9 ( 6 1 . 5 )}$ & $\mathbf{5 2}$ \\
\hline
\end{tabular}

*Positive (ER/PR) status means ER or PR is positive, whereas negative ER/PR status means that the specimen is negative for both receptors. Nuc-pYStat5, nuclear localized and tyrosine phosphorylated Stat5; GLUT1, glucose transporter 1; PrIR, prolactin receptor; IDC, invasive ductal carcinoma; ILC, invasive lobular carcinoma; ER, estrogen receptor; PR, progesterone receptor.

of breast cancer cells by analyzing prolactin-induced phosphorylation of Stat5 and Erk over a pathophysiological $\mathrm{pH}_{\mathrm{e}}$ range from 7.4 to 6.6. Indeed, in both T47D (Figure 2B) and SKBR3 cells (Figure 2C), prolactin-induced Stat5 and Erk phosphorylation were gradually reduced with decreasing $\mathrm{pH}_{\mathrm{e}}$. Prolactin-stimulated Stat5 and Erk phosphorylations in both cell lines were diminished by $80 \%$ or more at $\mathrm{pH}_{\mathrm{e}} 6.8$ compared with phosphorylation at $\mathrm{pH}_{\mathrm{e}} 7.4$ $(p<0.01)$. Even at $\mathrm{pH}_{\mathrm{e}} 7.0$, only $0.4 \mathrm{pH}$ units below normal tissue $\mathrm{pH}$ of 7.4, a statistically significant decrease in pYStat5 levels was detected. Prolactin signaling in SKBR3 cells was particularly sensitive to extracellular acidosis, possibly because prolactin receptor levels in SKBR3 cells are lower than in T47D cells.

\section{Acidosis-induced disruption of prolactin signaling is resistant to high prolactin concentrations}

We next determined whether increasing concentrations of prolactin could overcome acidosis-suppression of prolactin signaling. SKBR3 and T47D breast cancer cell lines were stimulated with prolactin concentrations ranging from 1 to $100 \mathrm{nM}$ for 15 min at different $\mathrm{pH}_{\mathrm{e}}$. At $\mathrm{pH}_{\mathrm{e}}$ of 7.4, Stat5 phosphorylation was detectably induced by $1 \mathrm{nM}$ prolactin and reached maximum levels at $10 \mathrm{nM}$ prolactin in both cell lines (Figure 3A). In contrast, in both cell lines at $\mathrm{pH}_{\mathrm{e}}$ of 6.8 , prolactin activation of Stat5 was greatly suppressed at all prolactin concentrations tested. SKBR3 cells were tested also at $\mathrm{pH}_{\mathrm{e}}$ of 6.5, which completely abolished Stat5 activation even at $100 \mathrm{nM}$ of prolactin. Estimated half maximal effective concentration $\left(\mathrm{EC}_{50}\right)$ values were at least 10 -fold higher at $\mathrm{pH}_{\mathrm{e}}$ of 6.8 than at $7.4(119.0 \mathrm{nM}$ vs. $3.3 \mathrm{nM}$ for SKBR3, $37.8 \mathrm{nM}$ vs. $3.7 \mathrm{nM}$ for T47D) (Figure 3B). Furthermore, a time course study up to 120 min eliminated the possibility that acidosis simply transiently suppressed and delayed prolactin receptor activation (Figure 3C). At $\mathrm{pH}_{\mathrm{e}}$ of 7.4 prolactin-induced Stat5 activation peaked within 15 min, dropping slightly thereafter in both cell lines, whereas prolactin-induced pYStat5 levels were greatly diminished at $\mathrm{pH}_{\mathrm{e}} 6.8$, without evidence of emergence of a delayed signal. Together, these data established that prolactin signaling in human breast cancer cells is highly sensitive to extracellular acidosis even at high prolactin concentrations and for extended periods.

\section{Prolactin receptor signaling is selectively sensitive to the inhibitory effect of acidic microenvironment}

Since earlier reports had revealed a compromised solution structure of prolactin at lower $\mathrm{pH}$ [41] with reduced ability to bind to prolactin receptors in surface plasmon resonance assays [32], we examined whether the suppressive effect of acidic $\mathrm{pH}$ is selective for prolactin receptor signaling or reflects a general effect on cell surface receptor signaling in cancer cells stressed by exposure to low $\mathrm{pH}_{\mathrm{e}}$. Whereas prolactin-induced phosphorylation of Stat5, Erk and Akt in SKBR3 cells were suppressed at $\mathrm{pH}_{\mathrm{e}}$ of 6.8 and 6.5. Erk activation induced by EGF showed no evidence of inhibition by extracellular acidosis, compared to the response at normal $\mathrm{pH}_{\mathrm{e}}$ of 7.4 (Figure 4A). Likewise, activation of Stat3 and Erk in SKBR3 cells by the proinflammatory cytokine, oncostatin $\mathrm{M}$ (OSM), was also unaffected by $\mathrm{pH}_{\mathrm{e}}$ of 6.8 (Figure 4B). Similar insensitivity to moderate acidosis was observed for insulin-like growth factor 1 (IGF1) and fibroblast growth factor (FGF) signaling (see Additional file 1). Thus, under acidic conditions that completely blocked prolactin-induced signaling, breast cancer cells remained viable and fully capable of responding to other extracellular factors. Furthermore, while prolactin effectively induced both c-jun and CISH transcripts in SKBR3 cells at $\mathrm{pH}_{\mathrm{e}}$ 7.4, transcript-inductions by prolactin but not EGF were markedly reduced at $\mathrm{pH}_{\mathrm{e}} 6.8(P<0.01)$ (Figure $\left.4 \mathrm{C}\right)$.

Human growth hormone $(\mathrm{GH})$ resembles prolactin in size and overall structure and is also implicated in breast cancer growth and development [42,43]. To examine whether $\mathrm{GH}$ receptor signaling is $\mathrm{pH}$ dependent, we stably expressed GHR or hPrlR in the GHR and PrlR-negative 32D murine myeloblast line. We examined Stat5 activation in 32D-hPrlR or 32DhGHR cells by the cognate ligands over a $\mathrm{pH}_{\mathrm{e}}$ range of 7.4 to 6.6 (Figure 4D). Whereas prolactin-induced Stat5 phosphorylation was gradually lost with increasing proton concentrations in 32D-hPrlR cells, GH-induced Stat5 activation was not suppressed over the same $\mathrm{pH}_{\mathrm{e}}$ range in 32D-hGHR cells (Figure 4D). These results 

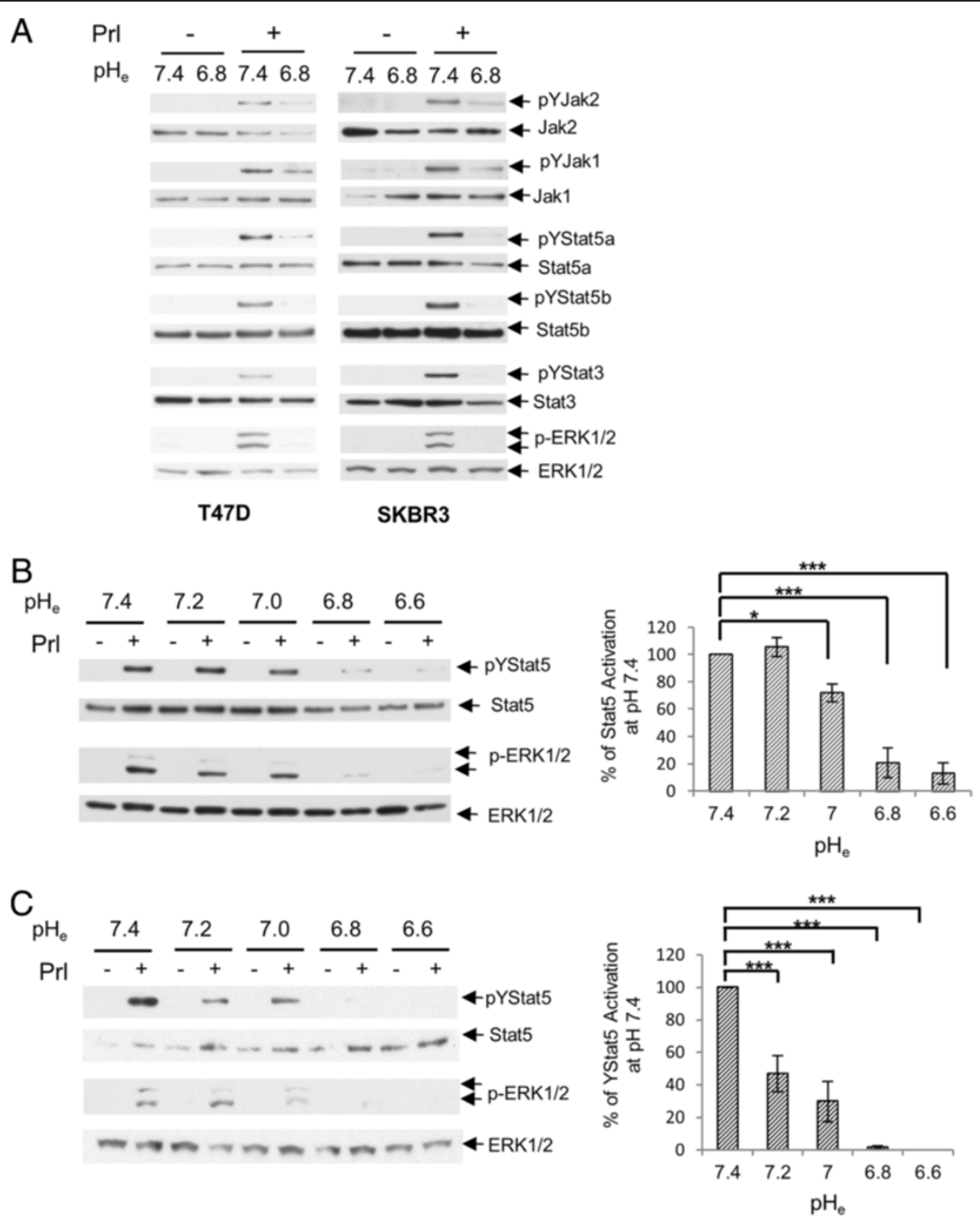

Figure 2 Prolactin signaling in breast cancer cells is markedly inhibited by moderate acidic $\mathbf{p H}_{\mathrm{e}}$. (A) T47D cells and SKBR3 cells were induced by prolactin or vehicle at $\mathrm{pH}_{\mathrm{e}} 7.4$ or 6.8. All major prolactin signaling pathways were examined. T47D (B) and SKBR3 (C) cells were induced by prolactin or vehicle at various $\mathrm{pH}_{\mathrm{e}}$ as indicated. Stat5 and Erk activation by prolactin was examined. Levels of Stat5 activation were analyzed by densitometry and plotted as mean $\pm \mathrm{SE}(n=3)$. The pYStat5 levels among different $\mathrm{pH}_{\mathrm{e}}$ conditions were analyzed by ANOVA, and followed by Fisher's least significant difference test. ANOVA, analysis of variance; $\mathrm{pH}_{\mathrm{e}}$, extracellular $\mathrm{pH}$; $\mathrm{SE}$, standard error. ${ }^{*}, p<0.05 ;{ }^{* *}, p<0.01$; ${ }^{* * *}, p<0.001$.

demonstrated that GH signaling via GHR is resistant to extracellular acidosis.

Human PrlR does not only bind human prolactin, but is capable of binding and responding to $\mathrm{GH}$, with zinc ions facilitating GH-hPrlR binding [44]. Many breast cancer cells express both GHR and PrlR. To test whether GH signaling in human T47D breast cancer cells, which express low levels of GHR and high levels of PrlR, is affected by extracellular acidosis, we assessed GH induction of phosphorylation of Jak2, Jak1 and Stat5 across a range of zinc ion concentrations at $\mathrm{pH}_{\mathrm{e}} 7.4$ and 6.8 (Figure 4E). Under zinc-free conditions $\mathrm{GH}$ signals in T47D cells were modest at normal $\mathrm{pH}_{\mathrm{e}}$ and were suppressed at acidic $\mathrm{pH}_{\mathrm{e}}$. Increasing concentrations of zinc ions enhanced $\mathrm{GH}$ signaling at $\mathrm{pH}_{\mathrm{e}}$ 7.4, presumably by enhancing GH binding to PrlR. Since circulating zinc ion concentrations in humans range from 1 to 20 $\mu \mathrm{M}$ [45], only at supraphysiological zinc ion concentrations of $50 \mu \mathrm{M}$ did $\mathrm{GH}$-induced signaling in T47D cells become $\mathrm{pH}_{\mathrm{e}}$-independent (Figure 4E). Collectively, our data indicates that at physiological zinc ion levels $\mathrm{GH}$ induced Stat 5 activation via PrlR, but not GHR, in breast cancer cells is significantly suppressed by moderate extracellular acidosis. 

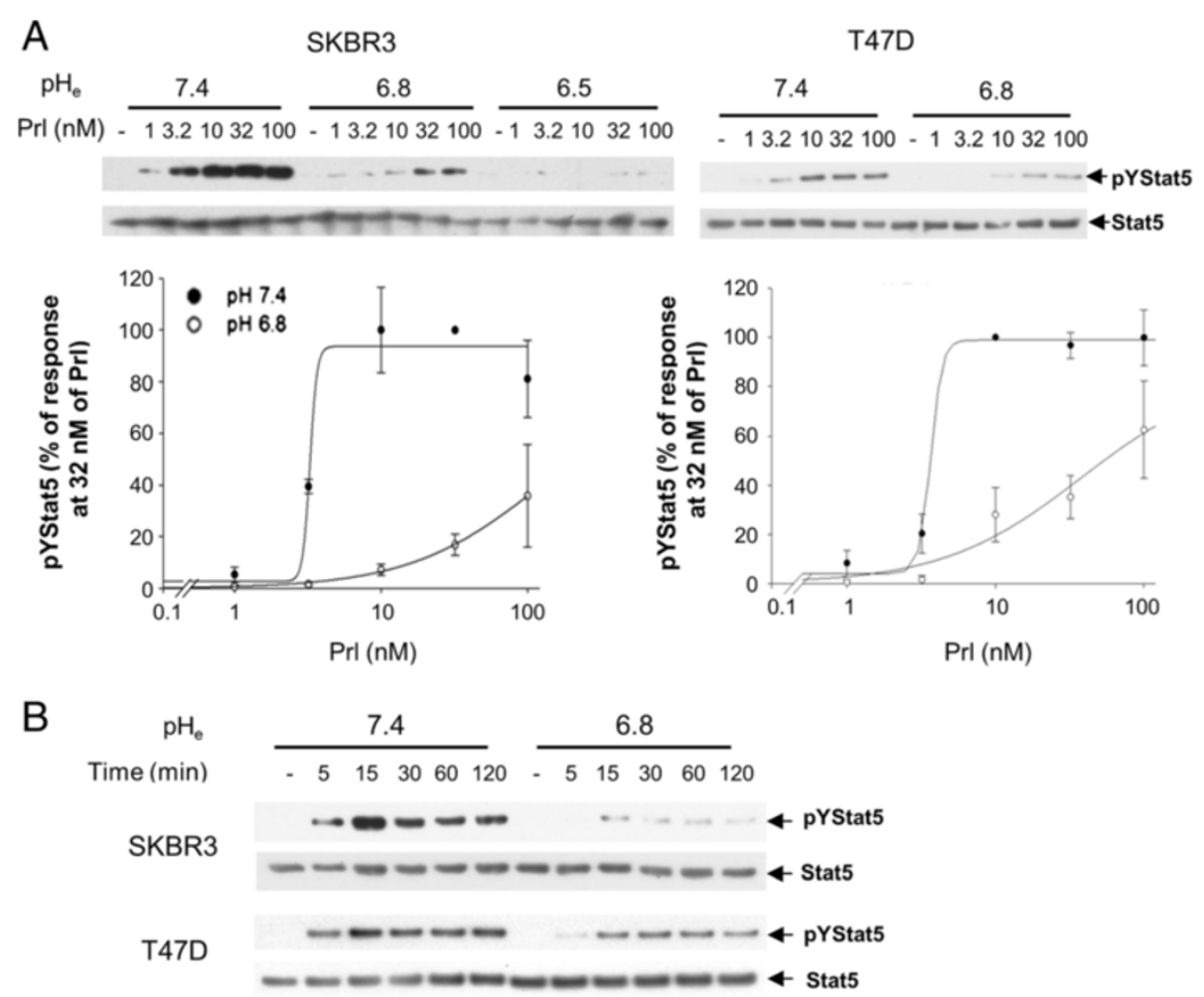

Figure 3 Dose-dependent response and time course of prolactin-induced Stat 5 tyrosine phosphorylation at different levels of $\mathrm{pH}_{\mathrm{e}}$. (A) Different concentrations of prolactin (1 to $100 \mathrm{nM}$ ) were used to induce SKBR3 or T47D cells at normal tissue $\mathrm{pH}_{\mathrm{e}}\left(\mathrm{pH}_{\mathrm{e}} 7.4\right)$ or acidic tumor $\mathrm{pH}_{\mathrm{e}}\left(\mathrm{pH}_{\mathrm{e}} 6.8\right.$ or $\mathrm{pH}_{\mathrm{e}}$ 6.5). Representative data on levels of pYStat5 and total Stat5 protein is presented with densitometric analyses shown representing independent experiments in SKBR3 $(n=4)$ and T47D $(n=3)$. (B) SKBR3 and T47D cells were treated with prolactin for indicated length of time and representative pYStat5 and Stat5 levels are shown $(n=4) . \mathrm{pH}_{\mathrm{e}}$, extracellular $\mathrm{pH}$.

\section{Inhibition of prolactin signaling by acidosis is rapidly reversible}

Our observation that all downstream signals are disrupted at reduced $\mathrm{pH}_{\mathrm{e}}$ and data from cell-free analyses [32,33] suggest that proton-induced disruption of prolactin signaling occurs at the level of ligand-receptor binding. However, acidosis might indirectly affect prolactin receptor signaling through additional mechanisms. We therefore tested whether restoration of physiological $\mathrm{pH}_{\mathrm{e}}$ could immediately rescue PrlR signaling, which would be consistent with a primary mechanism of direct disruption of ligand binding. SKBR3 cells were preincubated alternately at $\mathrm{pH}_{\mathrm{e}} 7.4$ or $\mathrm{pH}_{\mathrm{e}} 6.8$ for 30 min, before cells were exposed to medium containing prolactin or vehicle for $15 \mathrm{~min}$ at either the same $\mathrm{pH}_{\mathrm{e}}$ or the alternate $\mathrm{pH}_{\mathrm{e}}$, and prolactin-induced Stat5, Jak2 and Erk signals were examined. A third set of cells received additional $30 \mathrm{~min}$ incubation in the alternate $\mathrm{pH}_{\mathrm{e}}$ before prolactin exposure to determine whether prolonged reversal of $\mathrm{pH}_{\mathrm{e}}$ would be more effective than immediate reversal (Figure 5A). For cells preincubated at $\mathrm{pH} 7.4$, the inhibition of prolactin signals by $\mathrm{pH}_{\mathrm{e}} 6.8$ was immediate and not further strengthened by additional incubation at $\mathrm{pH}_{\mathrm{e}}$ 6.8. Likewise, rescue of prolactin signaling in
$\mathrm{pH}_{\mathrm{e}}$ 6.8-exposed cells was immediately restored upon exposure to prolactin at $\mathrm{pH}_{\mathrm{e}} 7.4$, and signals were not consistently further enhanced by prolonged incubation at $\mathrm{pH}_{\mathrm{e}} 7.4$ prior to prolactin stimulation.

To better experimentally model prolactin-acidosis relationships in tumors in vivo, we used three-dimensional T47D spheroids in culture to determine whether acidosis-induced suppression of prolactin signaling could be rapidly reversed by normalizing $\mathrm{pH}_{\mathrm{e}}$. Indeed, when three-dimensional spheroids of T47D cultures at $\mathrm{pH}_{\mathrm{e}} 6.8$ were equilibrated with prolactin for $2 \mathrm{~h}$ there was no detectable Stat 5 activation over control levels, whereas alkalinization of the medium to $\mathrm{pH} 7.4$ restored Stat5 activation within $5 \mathrm{~min}$ in prolactin-equilibrated spheroids (Figure 5B). Collectively, extracellular acidosis inhibits prolactin signaling in a rapid and reversible manner consistent with the principal mechanism being proton-dependent disruption of ligand-receptor binding.

\section{Markers of glucose uptake/glycolytic metabolism are} associated with loss of Nuc-pYStat5 signaling in invasive breast cancer and xenografts in mice

To further substantiate the observed mutually exclusive expression of the glucose transporter GLUT1 and Nuc- 


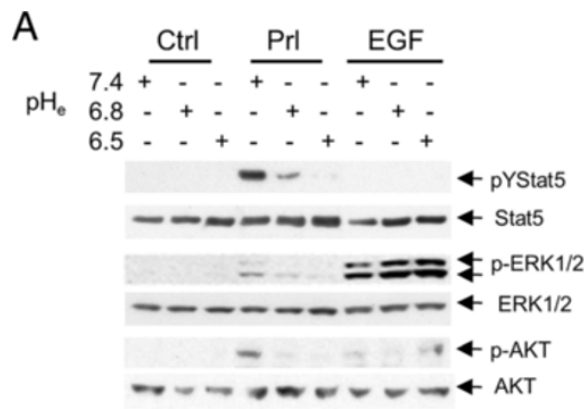

B

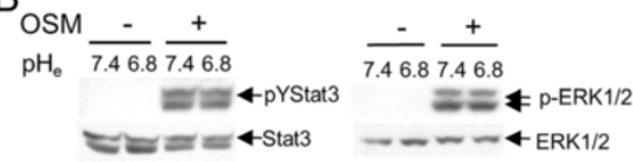

D 32D-hPrIR
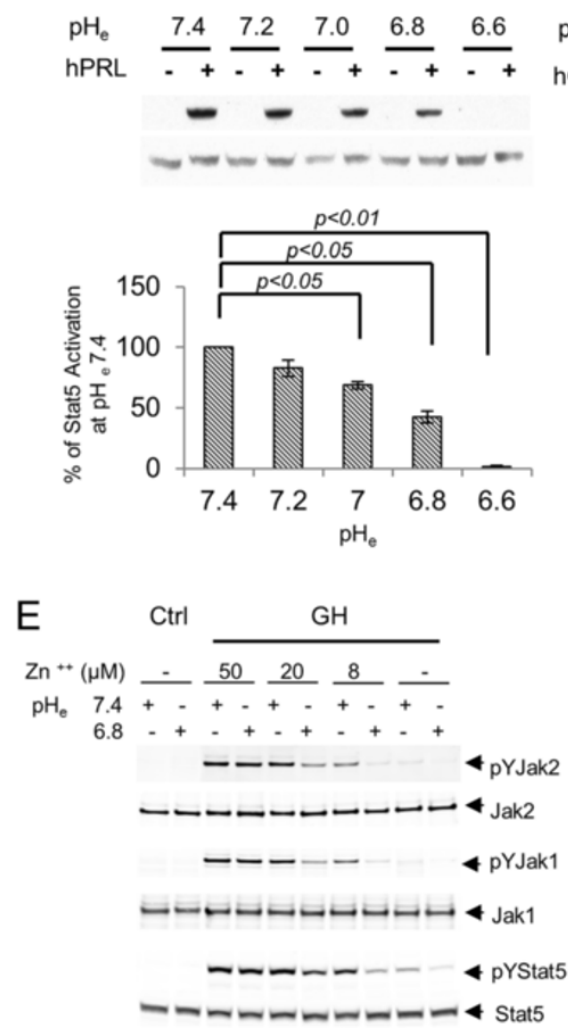
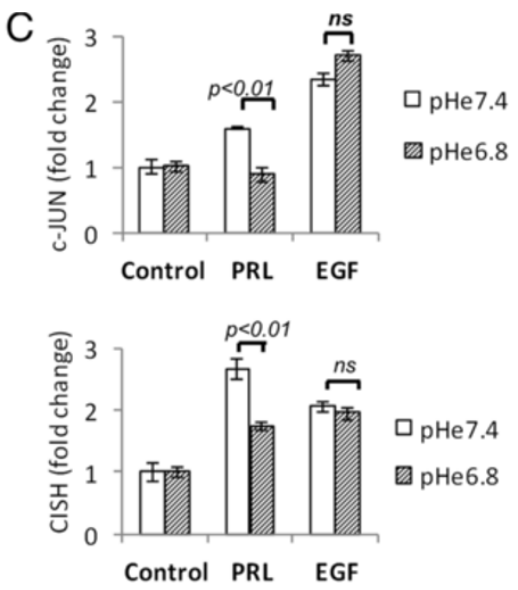

32D-hGHR
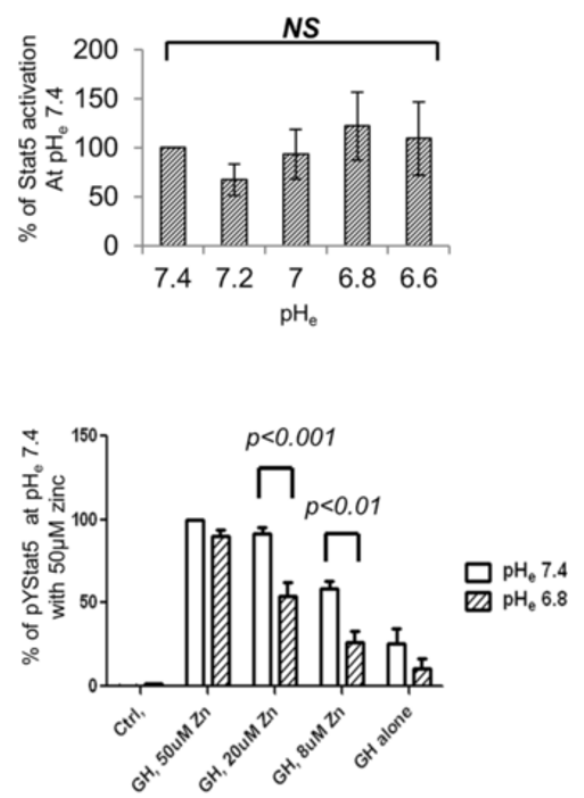

Figure $4 \mathrm{pH}_{\mathrm{e}}$ effect on prolactin receptor signaling is specific. (A) SKBR3 cells were stimulated with vehicle, prolactin or EGF for 30 min at different $\mathrm{pH}_{\mathrm{e}}$ as indicated. Stat5 and Erk phosphorylation were examined $(n=3)$. (B) SKBR3 cells were treated with vehicle or $10 \mathrm{nM}$ OSM for 15 min at $\mathrm{pH}_{\mathrm{e}} 7.4$ or 6.8. Representative Stat3 and Erk activation were shown $(n=2)$. (C) SKBR3 cells were treated with vehicle, prolactin or EGF for 1 hour at $\mathrm{pH}_{\mathrm{e}} 7.4$ or 6.8. Quantitative PCR of $c$-jun and CISH transcripts were conducted and representative results are shown in bar graphs ( $n=3$ ). (D) 32D-hPrlR cells were treated with $2 \mathrm{nM}$ prolactin at $\mathrm{pH}_{\mathrm{e}}$ range of 7.4 to $6.6(n=3)$. 32D-hGHR cells were treated with $2 \mathrm{nM}$ growth hormone at similar conditions $(n=5)$. Representative pYStat5 and total Stat5 blots are shown. Stat5 activation at each $\mathrm{pH}_{\mathrm{e}}$ were analyzed and compared. (E), $10 \mathrm{nM} \mathrm{GH}$-induced phosphorylation of Jak2, Jak1 and Stat5 at various zinc concentration were compared at normal and acidic tumor $\mathrm{pH}_{\mathrm{e}}$ in T47D cells $(n=4)$. One-way ANOVA was followed by Bonferroni's post hoc test. 32D-hGHR, human growth hormone receptor cells; 32D-hPrIR cells, mouse promyeloid 32D cells stably transfected with human prolactin receptor; ANOVA, analysis of variance; EGF, epidermal growth factor; $\mathrm{GH}$, human growth hormone; $\mathrm{pH}_{\mathrm{e}}$, extracellular $\mathrm{pH}$. 


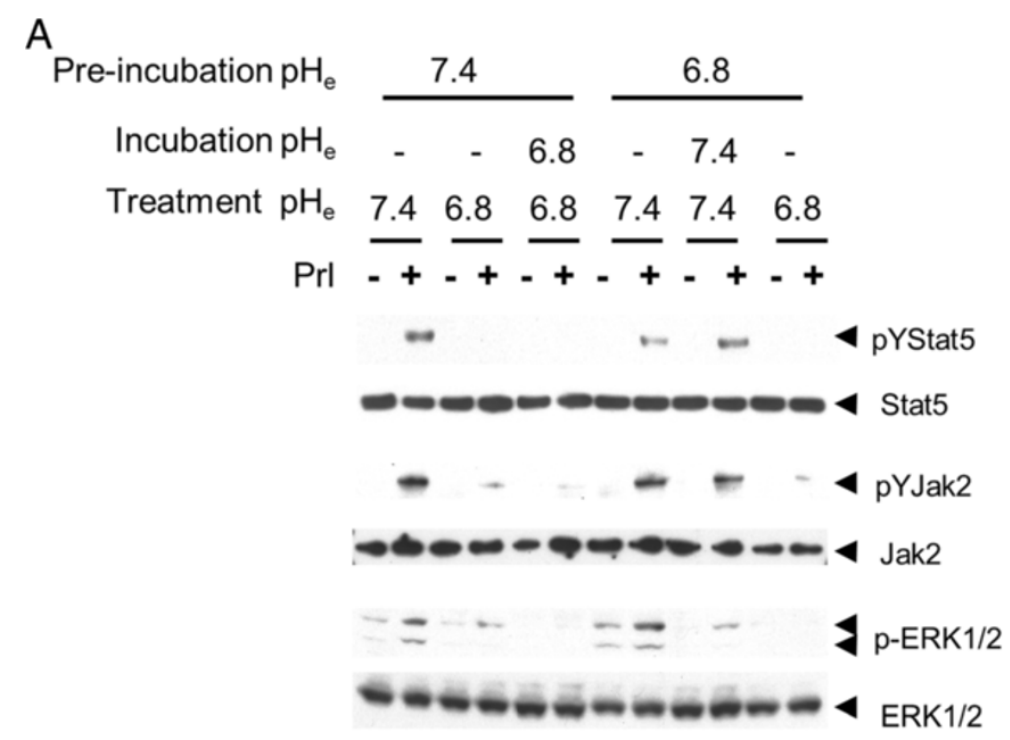

B
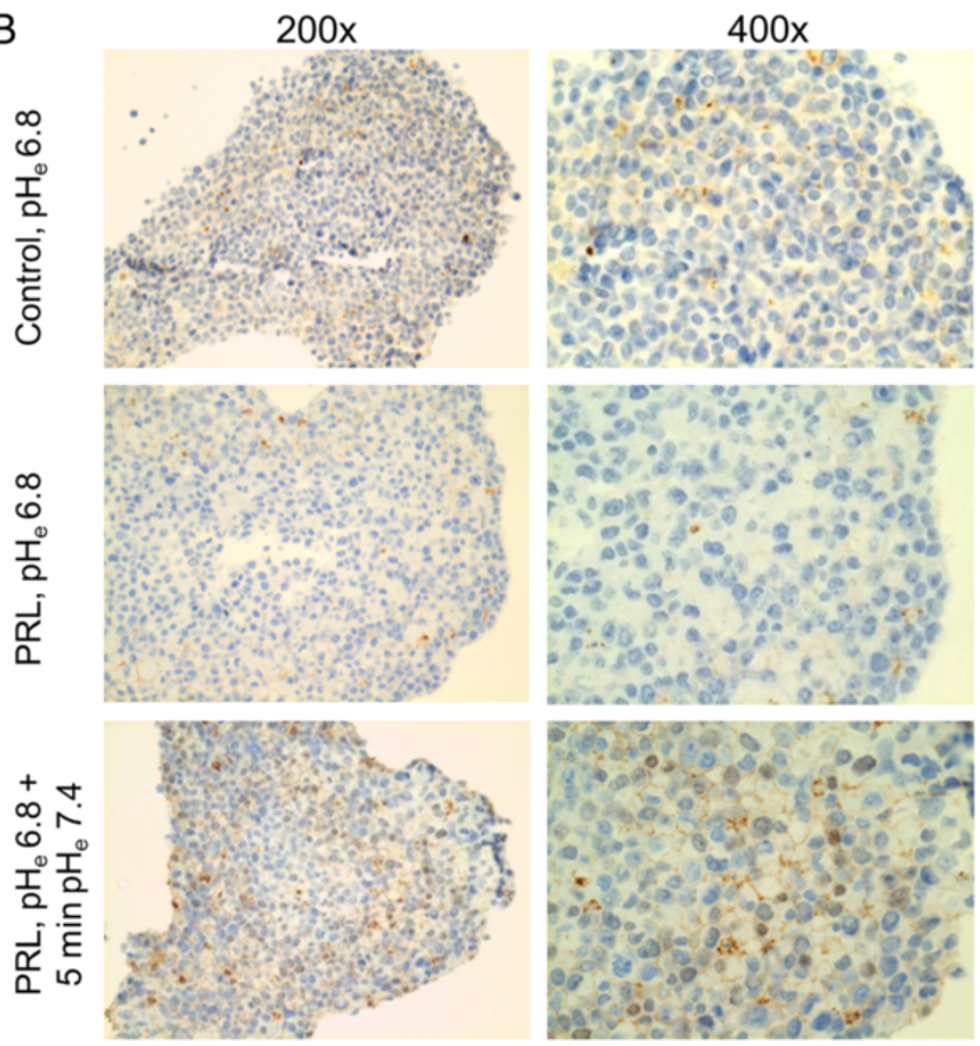

Figure $\mathbf{5} \mathrm{pH}_{\mathrm{e}}$ effect on prolactin signaling is rapidly reversible. (A) SKBR3 cells were preincubated with medium of either $\mathrm{pH}_{\mathrm{e}} 7.4$ or $\mathrm{pH}_{\mathrm{e}} 6.8$ for $30 \mathrm{~min}$ at $37^{\circ} \mathrm{C}$. Then the $\mathrm{pH}_{\mathrm{e}}$ was altered or not as indicated and cells were treated with prolactin for $15 \mathrm{~min}$. Two groups were incubated further for another 30 minutes as indicated before exposure to prolactin. Jak2, Stat5 and Erk activation was analyzed $(n=3)$. (B) T47D spheroids grown in three-dimensional culture conditions were treated with prolactin or vehicle at indicated pH conditions. The spheroids were stained for pYStat5. The experiment was carried out twice.

pYStat5 in tissue sections from Cohort I of clinical breast cancer cases, we examined a larger Cohort II of archival breast cancer tissues that also included normal controls. Normal breast epithelia generally displayed high levels of Nuc-pYStat5 and low levels of GLUT1. Representative tissue sections of normal breast tissue stained for either pYStat5 or GLUT1 along with two cases of invasive breast cancer that are positive for either 
Nuc-pYStat5 or GLUT1 are shown (Figure 6A). Levels of GLUT1 and Nuc-pYStat5 within the epithelial compartment were quantified for each specimen of Cohort II using AQUA and presented as a scatter plot stratified by diagnostic categories (Figure 6B). GLUT1 membrane staining was generally undetectable in normal breast epithelia but was elevated in a subset of invasive breast carcinomas (Figure 6B). Consistent with previous reports $[27,38]$, Nuc-pYStat5 levels were high in the epithelia of healthy breast tissues and reduced in many of the invasive ductal carcinomas (IDCs). GLUT1-positive breast cancer cases not only displayed reduced Nuc-pYStat5 staining, but also represented more progressive disease, such as higher grade of cancer or lymph node metastases. Among malignant breast specimens, levels of NucpYStat5 were substantially lower in GLUT1-positive cases than in GLUT1-negative cases $(p<0.001)$, whereas expression levels of Stat5a, Stat5b and PrlR did not differ between the two groups (Figure 6C). We further partitioned malignant breast cancer specimens into low and high Nuc-pYStat 5 based on the range in healthy breast tissues. Consistent with the data of Cohort I of 52 invasive breast cancer specimens, high GLUT1 levels were associated with low Nuc-pYStat5 levels in the invasive breast cancer specimens of Cohort II $(\mathrm{N}=88$; $p=0.01$, Fisher's exact test).

We further detected regional co-expression of GLUT1 and the key glycolytic enzyme, lactate dehydrogenase- 5 (LDH5), in T47D xenotransplants indicative of localized glycolytic metabolism and lactic acid production within the tumors (Figure 6D). In contrast, expression of PrlR and Stat5 proteins were largely uniform within the xenotransplants, regardless of glycolytic markers. We therefore hypothesized that GLUT1-positive T47D tumor regions would be resistant to exogenous human prolactin. Consistent with local acidosis within T47D tumors, in vivo $\mathrm{pH}$ measurement by microelectrode probe revealed a variably acidic tumor interstitium averaging $\mathrm{pH}_{\mathrm{e}}$ of $6.61 \pm 0.11(n=9)$, significantly lower than $\mathrm{pH}_{\mathrm{e}}$ of mouse peritoneal cavity at $7.25 \pm 0.04(n=3 ; p<0.001$ by Student's $t$ test). We injected human prolactin or vehicle into nude mice bearing T47D human xenografts and collected tumors $1 \mathrm{~h}$ later. When tumor sections were co-stained for pYStat5 and GLUT1, all T47D xenografts were regionally positive for GLUT1 staining (Figure 6E). Consistent with local acidosis-mediated suppression of prolactin signaling, GLUT1-positive regions as well as the immediately surrounding zone lacked prolactin-inducible pYStat5 response whereas regions of GLUT1-negative tumor cells displayed robust pYStat5 signal (Figure 6E). These in vivo experiments confirmed the presence of interstitial acidosis and regionally increased glucose uptake and glycolytic metabolism in T47D xenotransplants, and established selective unresponsiveness of GLUT1-positive tumor regions to exogenous human prolactin.

\section{Discussion}

The present study supports the novel pathophysiological concept that extracellular acidosis within the microenvironment of breast cancer potently and selectively disrupts prolactin receptor signaling, including Stat5 activation. Previous analyses of more than 2,000 cases revealed that loss of nuclear translocated and tyrosine phosphorylated Stat5 (Nuc-pYStat5) occurs frequently in breast cancer, and correlates with disease progression, poor prognosis, and increased risk of resistance to endocrine therapy [27-30]. Intratumoral acidosis is a previously unrecognized factor contributing to loss of prolactin-induced Nuc-pYStat5 human breast cancer, and implicates acidosis-associated prolactin resistance as a novel mechanism by which breast cancer cells escape pro-differentiation and invasion-suppressive effects of prolactin.

The pathophysiological relevance of potent and reversible acidosis-disruption of prolactin signaling in breast cancer is supported by extensive experimental evidence and correlative studies in archival human breast cancer specimens provided clinical relevance. Indeed, we observed mutually exclusive expression patterns of NucpYStat5, a marker of prolactin receptor activation, and elevated levels of GLUT1, a marker of increased glycolysis and associated lactacidosis. Quantitative multiplexed immunofluorescence analyses specifically revealed that positive GLUT1 expression (gain-of-function) was associated with low levels of Nuc-pYStat5 (loss-of-function) in malignant breast tumors at three different scales: at the global tumor level, regionally within tumors, and at the cellular level. This is consistent with global and regional acidosis within malignant breast tumors. However, a substantial number of tumors, tumor regions, or tumor cells were negative for both GLUT1 and NucpYStat5, indicating that not all tumor-associated absence of Stat5 signaling is explainable by GLUT1-associated acidosis in breast carcinoma cells. For instance, acidosis may in some cases be caused by increased glycolysis within stromal fibroblasts [6], which is not correlated with epithelial GLUT1 staining. Furthermore, alternative mechanisms likely lead to loss of Nuc-pYStat5 in human breast cancer, such as inhibition of prolactin-Stat5 signaling by the tyrosine phosphatase PTP1B through inhibition of the Jak2 tyrosine kinase [46].

Aerobic glycolysis in carcinoma cells is frequently associated with activated oncogenes, including Src, Myc, AKT/mTOR pathway and mutation of tumor suppressors such as p53 [47]. In these cases, the entire tumor typically displays glycolytic metabolism regardless of oxygenation status. In fact, we observed that more than 

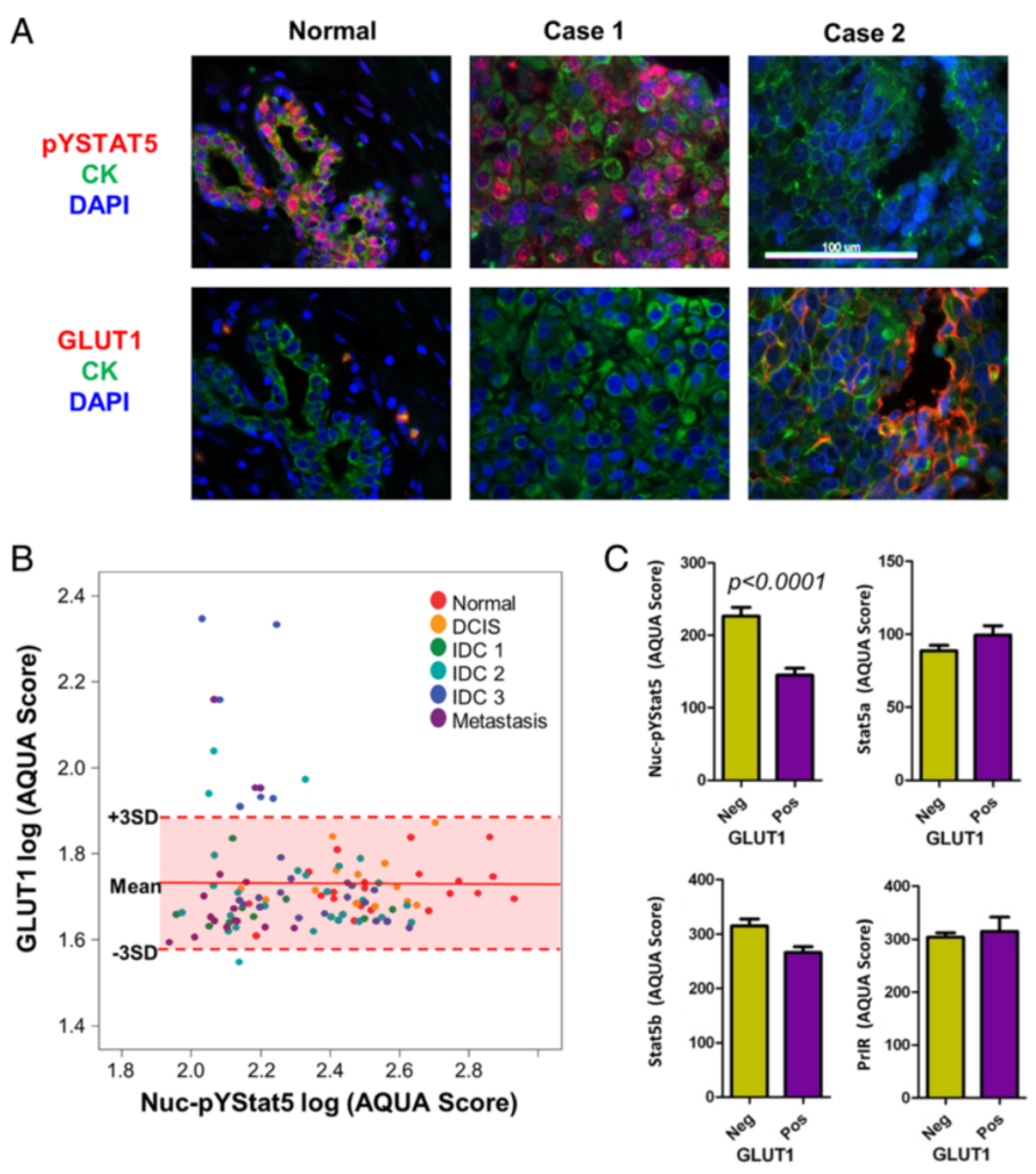

D

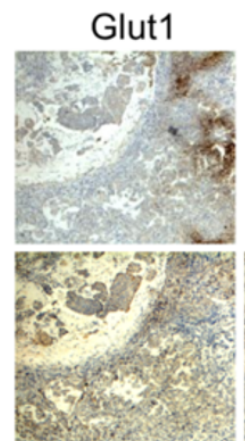

\section{PrIR}

LDH5

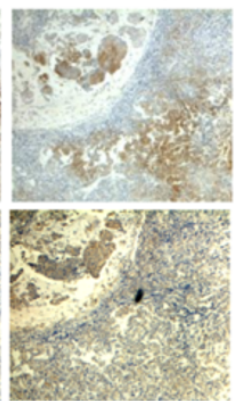

Stat5

E
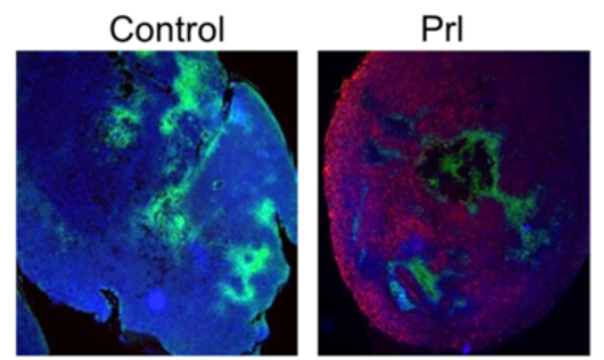

Figure 6 Elevated GLUT1 is associated with low Nuc-pYStat5 in human breast cancer and xenografts. (A) Representative images from a breast cancer progression tissue array co-stained with anti-cytokeratins, DAPI, anti-pYStat5 or anti-GLUT1. (B) Expression of GLUT1 and nuclear pY-Stat5 in each tissue samples were quantified by AQUA and plotted. The range of normal GLUT1 expression is labeled on the plot by mean of normal mammary gland GLUT1 (log) score \pm 3 SD. (C) Comparison of AQUA scores Nuc-pYStat5, Stat5a, Stat5b and PrIR between GLUT1 negative and positive breast cancer samples $(n=88$ ) by Student's $t$ test. (D) IHC staining of LDH5, GLUT1, PrIR and Stat5 with consecutive slides of a representative T47D xenograft tumor. (E) Co-staining of pYStat5 and GLUT1 in representative T47D xenografts from mice that were injected intraperitoneally with vehicle or human prolactin. Red, pYStat5; green, GLUT1. AQUA, automated quantitative analysis; GLUT1, glucose transporter 1; IHC, immunohistchemistry; LDH5, lactate dehydrogenase-5; Nuc-pYStat5, nuclear localized and tyrosine phosphorylated Stat5; PrIR, prolactin receptor; SD, standard deviation. 
half of the GLUT1-positive human breast cancer specimens displayed generally homogenous GLUT1 staining throughout the tumor and were essentially negative for Nuc-pYStat5. Alternatively, rapidly proliferating tumors may exhibit regional hypoxia with resulting focal or regional hypoxia-induced glycolysis and acidosis. Indeed, heterogeneous GLUT1 staining in breast tumors was also commonly detected, including specimens with GLUT1positive foci surrounding necrotic regions suggestive of local hypoxia. More recently, paracrine hepatocyte growth factor from cancer-associated fibroblasts was shown to promote GLUT1 expression and the Warburg effect in cancer [48]. Regardless of the mechanisms underlying increased regional glucose metabolism and extracellular acidosis, carcinoma cells positive for Nuc-pYStat 5 were absent in tumor regions where carcinoma cells displayed elevated GLUT1. Experimental evidence for acidosisinduced suppression of prolactin signaling in breast cancer was extended from cell lines in two-dimensional cultures to human breast cancer xenotransplants in mice in vivo and to multilayered three-dimensional spheroid cultures, experimental conditions that better mimic local acidosis within the patient tumor microenvironment. In fact, T47D xenotransplant tumor regions expressing high GLUT1 were resistant to exogenous prolactin despite retaining prolactin receptor and Stat5 expression. Furthermore, in three-dimensional spheroids of T47D cells extracellular alkalinization alone rapidly reversed acidosis-disrupted prolactin signaling. These observations are consistent with the notion that elevated glycolysis and lactacidosis effectively disrupts prolactininduced Nuc-pYStat5 in breast cancer.

The sensitivity of prolactin-induced signaling to acidosis is most likely due to a mechanism that involves protonation of histidine residues located at the ligandreceptor binding interface $[33,49]$. Four histidine residues are directly involved in high-affinity binding between prolactin and its cognate receptor based on crystal structures [41]. In contrast, histidine residues are not critical for binding of the closely related but acidosis-resistant growth hormone to its cognate GHR [50]. Mutational analyses have suggested that H180 of prolactin and $\mathrm{H} 188$ of PrlR are particularly important for the $\mathrm{pH}$-dependent ligand-receptor binding. Importantly, human GH can also bind to hPrlRs and exert lactogenic activity [51]. The binding of GH to hPrlRs is facilitated by a critical $\mathrm{Zn}^{2+}$ binding site formed by two growth hormone residues (H18 and E174) and two prolactin receptor residues (D187 and H188) at the binding interface [52]. Therefore, protonation of prolactin receptor $\mathrm{H} 188$ at acidic $\mathrm{pH}$ may interfere with $\mathrm{Zn}^{2+}$-mediated binding of $\mathrm{GH}$, and consequently disrupt the majority of GH-induced PrlR signaling in T47D cells. Only in the presence of supraphysiological concentrations of $\mathrm{Zn}^{2+}$
$(50 \mu \mathrm{M})$ did $\mathrm{GH}$-induced signaling become resistant to acidosis in T47D cells. This effect is probably due to stabilization of the histidine imidazole group at high $\mathrm{Zn}^{2+}$ concentration, which might protect PrlR H188 from becoming protonated. These observations are consistent with an earlier report based on a cell-free assay that the binding of $\mathrm{GH}$ to the PrlR extracellular domain was not $\mathrm{pH}$-dependent in the presence high levels of $\mathrm{Zn}^{2+}$ [33]. Importantly, GH signaling through PrlRs, including proposed heterodimerization of PrlRs and GHRs [53], is likely to remain $\mathrm{pH}_{\mathrm{e}}$-dependent at physiologic $\mathrm{Zn}^{2+}$ levels. In contrast, GH activation of GHRs expected to be unaffected by acidosis.

In addition to the full-length or 'long' PrlR, alternative mRNA splicing generates 'intermediate' and 'short' PrlR isoforms that only differ in their cytoplasmic domain. Binding of prolactin to these PrlR isoforms is expected to remain sensitive to acidosis. On the other hand, binding of prolactin to the $\triangle \mathrm{S} 1$ PrlR isoform may be less sensitive to acidosis due to its already poor ligand-binding kinetics caused by partial loss of the ligand-binding interface [54]. Furthermore, $16 \mathrm{~K}$ prolactin is an N-terminal proteolytic fragment of prolactin that comprises only the first 145 amino acid residues. Therefore, $16 \mathrm{~K}$ prolactin lacks the critical H180 residue which mediates $\mathrm{pH}_{\mathrm{e}}$-sensitive binding of $\mathrm{Prl}$ to PrlR. Despite the well-documented anti-angiogenesis activity of $16 \mathrm{~K}$ prolactin, the receptor mediating its function remains to be identified, and the effect of acidosis on the function of $16 \mathrm{~K}$ prolactin is unknown. Interestingly, $16 \mathrm{~K}$ prolactin is generated by cathepsin $\mathrm{D}$ cleavage of full length prolactin [55]. Cathepsin D is a lysosomal protease and thought to be active only at lysosomal $\mathrm{pH}$ range (approximately 5.0). More recent studies suggested that cathepsin $\mathrm{D}$ could be secreted and activated at acidic $\mathrm{pH}_{\mathrm{e}}$ approximately 6.7 [56]. Therefore, an acidic tumor environment might facilitate cleavage of full length prolactin into $16 \mathrm{~K}$ prolactin.

\section{Conclusions}

In summary, the prolactin-Jak2-Stat5 pathway, which may suppress breast cancer cell epithelial-to-mesenchymal transition, invasion and drug resistance [21-23], is potently and selectively suppressed by extracellular tumor acidosis. Local acidosis within the breast cancer microenvironment may represent a significant contributor to loss of Nuc-pYStat5 detected in clinical breast cancer specimens and thereby promote progression and evolution of more invasive and therapyresistant disease. Studies are warranted to determine how extracellular tumor acidosis impacts pharmacological strategies centered on targeting prolactin receptor pathways $[57,58]$ in breast cancer and potentially other malignancies. 


\section{Additional file}

Additional file 1: FGF and IGF1 signaling was not affected by acidic $\mathrm{pH}_{\mathrm{e}}$. SKBR3 cells were treated with FGF $(20 \mathrm{ng} / \mathrm{ml})$ or IGF1 $(100 \mathrm{ng} / \mathrm{ml})$ for 15 min at either $\mathrm{pH}_{\mathrm{e}} 7.4$ or 6.8 . Representive immunoblots of pErk1/2 and Erk are shown $(n=3)$. FGF, fibroblast growth factor; IGF1, insulin-like growth factor $1 ; \mathrm{pH}_{\mathrm{e}}$, extracellular $\mathrm{pH}$.

\section{Abbreviations}

pHe, extracellular pH; 32D-hGHR: human growth hormone receptor cells; 32D-hPrIR cells: mouse promyeloid 32D cells stably transfected with human PrIR; ANOVA: analysis of variance; AQUA: automated quantitative analysis; Cl: confidence interval; DAPI: 4',6-diamidino-2-phenylindole; $\mathrm{EC}_{50}$ : half maximal effective concentration; EGF: epidermal growth factor; ER: estrogen receptor; FCS: fetal calf serum; FGF: fibroblast growth factor; $h \mathrm{GH}$ : human growth hormone; hGHR: human growth hormone receptor; GLUT1: glucose transporter 1; hPrIR: human prolactin receptors; IDC: invasive ductal carcinoma; IGF1: insulin-like growth factor 1; IHC: immunohistochemistry; LDH5: lactate dehydrogenase-5; Nuc-pYStat5: nuclear localized and tyrosine phosphorylated Stat5; OSM: oncostatin $\mathrm{M}_{\text {; }} \mathrm{pH}_{\mathrm{e}}$ : extracellular $\mathrm{pH}$; PR: progesterone receptor; SE: standard error; Stat5a: signal transducer and activator of transcription-5a; Stat5b: signal transducer and activator of transcription-5b.

\section{Competing interests}

The authors declare that they have no competing interests.

\section{Authors' contributions}

$N Y, A R P, C L, T T, B F, I C, T H, C D S, J A H, A J K$ and HR conceived the study and participated in its design. JAH, AJK, CDS, THT and HR provided formalin-fixed, paraffin-embedded archived patient materials for the study. CL, MAG and ARP performed immunostaining, and quantitative immunofluorescence analyses. JAH, AJK and CDS conducted pathologic reviews and clinical data evaluations. ARP, BF, IC, TH, NY, ARP and HR performed statistical analyses. TT cultured three-dimensional T47D spheroids. FEU generated 32D-hPrIR and 32D-hGHR cell lines. AFY and NY conducted in vivo and in vitro experiments. NY and HR drafted the manuscript. All authors read, edited and approved the final manuscript.

\section{Acknowledgements}

We thank Dr. Dennis Leeper and Mathew Thakur for helpful discussions and advice, and Jessica Davison for expert editorial assistance. This work was supported by Komen for the Cure Promise Grant KG091116 (HR, TH, JAH, AJK, CDS, TS, ARP, MAG, CL, BF and IC), NIH grants CA101841 and CA118740 (HR), and NCl Support Grant 1P30CA56036 to the Kimmel Cancer Center. The Project is funded, in part, under a Commonwealth University Research Enhancement Program grant with the Pennsylvania Department of Health (HR). The Department specifically disclaims responsibility for any analyses, interpretations or conclusions. The views expressed in this article are those of the authors and do not reflect the official policy of the Department of the Army (DOA), Department of Defense (DOD), or US Government.

\section{Author details}

${ }^{1}$ Department of Cancer Biology, Kimmel Cancer Center, Thomas Jefferson University, 233 South 10th Street, Philadelphia, PA 19107, USA. ²Department of Pathology, Kimmel Cancer Center, Thomas Jefferson University, 233 South 10th Street, Philadelphia, PA 19107, USA. ${ }^{3}$ Department of Medical Oncology, Kimmel Cancer Center, Thomas Jefferson University, 233 South 10th Street, Philadelphia, PA 19107, USA. ${ }^{4}$ Department of Pharmaceutical Sciences, Thomas Jefferson University, Jefferson School of Pharmacy, 130 South 9th Street, Philadelphia, PA 19107, USA. ${ }^{5}$ Department of Pharmacology and Experimental Therapeutics, Division of Biostatistics, Thomas Jefferson University, 1015 Chestnut Street, Philadelphia, PA 19107, USA. 'MDR Global

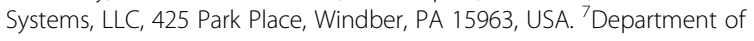
Surgery, Walter Reed National Military Medical Center, 8901 Wisconsin Avenue, Bethesda, MD 20814, USA. ${ }^{8}$ Department of Cancer Biology, Thomas Jefferson University, 233 South 10th Street, BLSB 330, Philadelphia, PA 19107, USA.
Received: 11 April 2013 Accepted: 12 July 2013

Published: 3 September 2013

\section{References}

1. Gillies RJ, Verduzco D, Gatenby RA: Evolutionary dynamics of carcinogenesis and why targeted therapy does not work. Nat Rev Cancer 2012, 12:487-493.

2. Zhang $X$, Lin Y, Gillies RJ: Tumor pH and its measurement. J NuCl Cardiol 2010, 51:1167-1170.

3. Wike-Hooley JL, van den Berg AP, van der Zee J, Reinhold HS: Human tumour pH and its variation. Eur J Cancer Clin Oncol 1985, 21:785-791.

4. Engin K, Leeper DB, Cater JR, Thistlethwaite AJ, Tupchong L, McFarlane JD: Extracellular $\mathrm{pH}$ distribution in human tumours. Int J Hyperthermia 1995, 11:211-216.

5. Montcourrier P, Silver I, Farnoud R, Bird I, Rochefort H: Breast cancer cells have a high capacity to acidify extracellular milieu by a dual mechanism. Clin Exp Metastasis 1997, 15:382-392.

6. Pavlides S, Whitaker-Menezes D, Castello-Cros R, Flomenberg N, Witkiewicz AK, Frank PG, Casimiro MC, Wang C, Fortina P, Addya S, Pestell RG, MartinezOutschoorn UE, Sotgia F, Lisanti MP: The reverse Warburg effect: aerobic glycolysis in cancer associated fibroblasts and the tumor stroma. Cell Cycle 2009, 8:3984-4001.

7. Chen KH, Tung PY, Wu JC, Chen Y, Chen PC, Huang SH, Wang SM: An acidic extracellular $\mathrm{pH}$ induces Src kinase-dependent loss of betacatenin from the adherens junction. Cancer Lett 2008, 267:37-48.

8. Gatenby RA, Gawlinski ET, Gmitro AF, Kaylor B, Gillies RJ: Acid-mediated tumor invasion: a multidisciplinary study. Cancer Res 2006, 66:5216-5223.

9. Fischer K, Hoffmann P, VoelkI S, Meidenbauer N, Ammer J, Edinger M, Gottfried E, Schwarz S, Rothe G, Hoves S, Renner K, Timischl B, Mackensen A, Kunz-Schughart L, Andreesen R, Krause SW, Kreutz M: Inhibitory effect of tumor cell-derived lactic acid on human T cells. Blood 2007, 109:3812-3819.

10. Rofstad EK, Mathiesen B, Kindem K, Galappathi K: Acidic extracellular pH promotes experimental metastasis of human melanoma cells in athymic nude mice. Cancer Res 2006, 66:6699-6707.

11. Robey IF, Baggett BK, Kirkpatrick ND, Roe DJ, Dosescu J, Sloane BF, Hashim Al, Morse DL, Raghunand N, Gatenby RA, Gillies RJ: Bicarbonate increases tumor pH and inhibits spontaneous metastases. Cancer Res 2009, 69:2260-2268.

12. Walenta S, Salameh A, Lyng H, Evensen JF, Mitze M, Rofstad EK, MuellerKlieser W: Correlation of high lactate levels in head and neck tumors with incidence of metastasis. Am J Pathol 1997, 150:409-415.

13. Walenta S, Wetterling M, Lehrke M, Schwickert G, Sundfor K, Rofstad EK, Mueller-Klieser W: High lactate levels predict likelihood of metastases, tumor recurrence, and restricted patient survival in human cervical cancers. Cancer Res 2000, 60:916-921.

14. Arendt LM, Rugowski DE, Grafwallner-Huseth TA, Garcia-Barchino MJ, Rui $H$, Schuler LA: Prolactin-induced mouse mammary carcinomas model estrogen resistant luminal breast cancer. Breast Cancer Res 2011, 13:R11.

15. Wennbo H, Gebre-Medhin M, Gritli-Linde A, Ohlsson C, Isaksson OG, Tornell $\mathrm{J}$ : Activation of the prolactin receptor but not the growth hormone receptor is important for induction of mammary tumors in transgenic mice. J Clin Invest 1997, 100:2744-2751.

16. Tworoger SS, Eliassen AH, Sluss $\mathrm{P}$, Hankinson SE: A prospective study of plasma prolactin concentrations and risk of premenopausal and postmenopausal breast cancer. J Clin Oncol 2007, 25:1482-1488.

17. Liu X, Robinson GW, Gouilleux F, Groner B, Hennighausen L: Cloning and expression of Stat5 and an additional homologue (Stat5b) involved in prolactin signal transduction in mouse mammary tissue. Proc Natl Acad Sci USA 1995, 92:8831-8835.

18. Nevalainen MT, Xie J, Bubendorf $L$, Wagner KU, Rui H: Basal activation of transcription factor signal transducer and activator of transcription (Stat5) in nonpregnant mouse and human breast epithelium. Mol Endocrinol 2002, 16:1108-1124.

19. Walker SR, Xiang M, Frank DA: Distinct roles of STAT3 and STAT5 in the pathogenesis and targeted therapy of breast cancer. Mol Cell Endocrinol 2013:S0303-7207. doi:10.1016/j.mce.2013.03.010. Epub ahead of print.

20. Sultan AS, Xie J, LeBaron MJ, Ealley EL, Nevalainen MT, Rui H: Stat5 promotes homotypic adhesion and inhibits invasive characteristics of human breast cancer cells. Oncogene 2005, 24:746-760. 
21. Nouhi Z, Chughtai N, Hartley S, Cocolakis E, Lebrun JJ, Ali S: Defining the role of prolactin as an invasion suppressor hormone in breast cancer cells. Cancer Res 2006, 66:1824-1832.

22. Sultan AS, Brim H, Sherif ZA: Co-overexpression of Janus kinase 2 and signal transducer and activator of transcription 5 a promotes differentiation of mammary cancer cells through reversal of epithelialmesenchymal transition. Cancer Sci 2008, 99:272-279.

23. Sato T, Tran TH, Peck AR, Girondo MA, Liu C, Goodman CR, Neilson LM, Freydin B, Chervoneva I, Hyslop T, Kovatich AJ, Hooke JA, Shriver CD, Fuchs SY, Rui H: Prolactin suppresses a progestin-induced CK5-positive cell population in luminal breast cancer through inhibition of progestin-driven BCL6 expression. Oncogene 2013. doi:10.1038/onc.2013.172. Epub ahead of print

24. Axlund SD, Yoo BH, Rosen RB, Schaack J, Kabos P, Labarbera DV, Sartorius CA: Progesterone-inducible cytokeratin 5-positive cells in luminal breast cancer exhibit progenitor properties. Horm Cancer 2013, 4:36-49.

25. Horwitz KB, Dye WW, Harrell JC, Kabos P, Sartorius CA: Rare steroid receptor-negative basal-like tumorigenic cells in luminal subtype human breast cancer xenografts. Proc Natl Acad Sci USA 2008, 105:5774-5779.

26. Kabos P, Haughian JM, Wang X, Dye WW, Finlayson C, Elias A, Horwitz KB, Sartorius CA: Cytokeratin 5 positive cells represent a steroid receptor negative and therapy resistant subpopulation in luminal breast cancers. Breast Cancer Res Treat 2011, 128:45-55.

27. Nevalainen MT, Xie J, Torhorst J, Bubendorf L, Haas P, Kononen J, Sauter G, Rui $\mathrm{H}$ : Signal transducer and activator of transcription-5 activation and breast cancer prognosis. J Clin Oncol 2004, 22:2053-2060.

28. Yamashita H, Nishio M, Ando Y, Zhang Z, Hamaguchi M, Mita K, Kobayashi S, Fujii $Y$, Iwase $H$ : Stat5 expression predicts response to endocrine therapy and improves survival in estrogen receptor-positive breast cancer. Endocr Relat Cancer 2006, 13:885-893.

29. Peck AR, Witkiewicz AK, Liu C, Stringer GA, Klimowicz AC, Pequignot E, Freydin B, Tran TH, Yang N, Rosenberg AL, Hooke JA, Kovatich AJ, Nevalainen MT, Shriver CD, Hyslop T, Sauter G, Rimm DL, Magliocco AM, Rui $\mathrm{H}$ : Loss of nuclear localized and tyrosine phosphorylated Stat5 in breast cancer predicts poor clinical outcome and increased risk of antiestrogen therapy failure. J Clin Oncol 2011, 29:2448-2458.

30. Peck AR, Witkiewicz AK, Liu C, Klimowicz AC, Stringer GA, Pequignot E, Freydin B, Yang N, Ertel A, Tran TH, Girondo MA, Rosenberg AL, Hooke JA, Kovatich AJ, Shriver CD, Rimm DL, Magliocco AM, Hyslop T, Rui H: Low levels of Stat5a protein in breast cancer are associated with tumor progression and unfavorable clinical outcomes. Breast Cancer Res 2012, 14:R130.

31. Wagner KU, Rui H: Jak2/Stat5 signaling in mammogenesis, breast cancer initiation and progression. J Mammary Gland Biol Neoplasia 2008, 13:93-103.

32. Keeler C, Jablonski EM, Albert YB, Taylor BD, Myszka DG, Clevenger CV, Hodsdon ME: The kinetics of binding human prolactin, but not growth hormone, to the prolactin receptor vary over a physiologic $\mathrm{pH}$ range. Biochemistry 2007, 46:2398-2410.

33. Kulkarni MV, Tettamanzi MC, Murphy JW, Keeler C, Myszka DG, Chayen NE, Lolis EJ, Hodsdon ME: Two independent histidines, one in human prolactin and one in its receptor, are critical for $\mathrm{pH}$-dependent receptor recognition and activation. J Biol Chem 2010, 285:38524-38533.

34. Hansen MJ, Olsen JG, Bernichtein S, O'Shea C, Sigurskjold BW, Goffin V, Kragelund BB: Development of prolactin receptor antagonists with reduced $\mathrm{pH}$-dependence of receptor binding. J Mol Recognit 2011, 24:533-547.

35. Neilson LM, Zhu J, Xie J, Malabarba MG, Sakamoto K, Wagner KU, Kirken RA, Rui $\mathrm{H}$ : Coactivation of janus tyrosine kinase (Jak)1 positively modulates prolactin-Jak2 signaling in breast cancer: recruitment of ERK and signal transducer and activator of transcription (Stat)3 and enhancement of Akt and Stat5a/b pathways. Mol Endocrinol 2007, 21:2218-2232.

36. Utama FE, LeBaron MJ, Neilson LM, Sultan AS, Parlow AF, Wagner KU, Rui H: Human prolactin receptors are insensitive to mouse prolactin: implications for xenotransplant modeling of human breast cancer in mice. J Endocrinol 2006, 188:589-601.

37. LeBaron MJ, Crismon HR, Utama FE, Neilson LM, Sultan AS, Johnson KJ Andersson EC, Rui H: Ultrahigh density microarrays of solid samples. Nat Methods 2005, 2:511-513

38. Tran TH, Utama FE, Lin J, Yang N, Sjolund AB, Ryder A, Johnson KJ, Neilson LM, Liu C, Brill KL, Rosenberg AL, Witkiewicz AK, Rui H: Prolactin inhibits BCL6 expression in breast cancer through a Stat5a-dependent mechanism. Cancer Res 2010, 70:1711-1721.
39. http://www.R-project.org.

40. Brown RS, Goodman TM, Zasadny KR, Greenson JK, Wahl RL: Expression of hexokinase II and Glut-1 in untreated human breast cancer. Nucl Med Biol 2002, 29:443-453.

41. Teilum K, Hoch JC, Goffin V, Kinet S, Martial JA, Kragelund BB: Solution structure of human prolactin. J Mol Biol 2005, 351:810-823.

42. Zhang X, Mehta RG, Lantvit DD, Coschigano KT, Kopchick JJ, Green JE, Hedayat S, Christov KT, Ray VH, Unterman TG, Swanson SM: Inhibition of estrogen-independent mammary carcinogenesis by disruption of growth hormone signaling. Carcinogenesis 2007, 28:143-150.

43. Brunet-Dunand SE, Vouyovitch C, Araneda S, Pandey V, Vidal LJ, Print C, Mertani HC, Lobie PE, Perry JK: Autocrine human growth hormone promotes tumor angiogenesis in mammary carcinoma. Endocrinology 2009, 150:1341-1352.

44. Cunningham BC, Bass S, Fuh G, Wells JA: Zinc mediation of the binding of human growth hormone to the human prolactin receptor. Science 1990, 250:1709-1712.

45. Breskin MW, Worthington-Roberts BS, Knopp RH, Brown Z, Plovie B, Mottet NK, Mills JL: First trimester serum zinc concentrations in human pregnancy. Am J Clin Nutr 1983, 38:943-953.

46. Johnson KJ, Peck AR, Liu C, Tran TH, Utama FE, Sjolund AB, Schaber JD, Witkiewicz AK, Rui H: PTP1B suppresses prolactin activation of Stat5 in breast cancer cells. Am J Pathol 2010, 177:2971-2983.

47. Jones RG, Thompson CB: Tumor suppressors and cell metabolism: a recipe for cancer growth. Genes Dev 2009, 23:537-548.

48. Brauer HA, Makowski L, Hoadley KA, Casbas-Hernandez P, Lang LJ, RomanPerez E, D'Arcy M, Freemerman AJ, Perou CM, Troester MA: Impact of tumor microenvironment and epithelial phenotypes on metabolism in breast cancer. Clin Cancer Res 2013, 19:571-585.

49. Keeler C, Tettamanzi MC, Meshack S, Hodsdon ME: Contribution of individual histidines to the global stability of human prolactin. Protein Sci 2009, 18:909-920.

50. Cunningham BC, Wells JA: Comparison of a structural and a functional epitope. J Mol Biol 1993, 234:554-563.

51. Chawla RK, Parks JS, Rudman D: Structural variants of human growth hormone: biochemical, genetic, and clinical aspects. Annu Rev Med 1983 34:519-547.

52. Somers W, Ultsch M, De Vos AM, Kossiakoff AA: The X-ray structure of a growth hormone-prolactin receptor complex. Nature 1994, 372:478-481.

53. Xu J, Zhang Y, Berry PA, Jiang J, Lobie PE, Langenheim JF, Chen WY, Frank SJ: Growth hormone signaling in human T47D breast cancer cells: potential role for a growth hormone receptor-prolactin receptor complex. Mol Endocrinol 2011, 25:597-610.

54. Kline JB, Roehrs H, Clevenger CV: Functional characterization of the intermediate isoform of the human prolactin receptor. J Biol Chem 1999 274:35461-35468.

55. Piwnica D, Touraine P, Struman I, Tabruyn S, Bolbach G, Clapp C, Martial JA Kelly PA, Goffin V: Cathepsin D processes human prolactin into multiple 16K-like N-terminal fragments: study of their antiangiogenic properties and physiological relevance. Mol Endocrinol 2004, 18:2522-2542.

56. Takenouchi T, Iwamaru Y, Sugama S, Tsukimoto M, Fujita M, Sekigawa A, Sekiyama K, Sato M, Kojima S, Conti B, Hashimoto M, Kitani H: The activation of $\mathrm{P} 2 \mathrm{X} 7$ receptor induces cathepsin D-dependent production of a 20-kDa form of IL-1 beta under acidic extracellular pH in LPS-primed microglial cells. J Neurochem 2011, 117:712-723.

57. Damiano JS, Rendahl KG, Karim C, Embry MG, Ghoddusi M, Holash J, Fanidi A, Abrams TJ, Abraham JA: Neutralization of prolactin receptor function by monoclonal antibody LFA102, a novel potential therapeutic for the treatment of breast cancer. Mol Cancer Ther 2013, 12:295-305.

58. Damiano JS, Wasserman E: Molecular pathways: blockade of the PRLR signaling pathway as a novel antihormonal approach for the treatment of breast and prostate cancer. Clin Cancer Res 2013, 19:1644-1650.

\section{doi:10.1186/bcr3467}

Cite this article as: Yang et al:: Prolactin-Stat5 signaling in breast cancer is potently disrupted by acidosis within the tumor microenvironment. Breast Cancer Research 2013 15:R73. 